\title{
THE INFLUENCE OF READING HABITSAND READING STRATEGIES ON STUDENTS' READING COMPREHENSION ATJUNIOR HIGH SCHOOL 1 IN THE DISTRICT OFBENAI- KUANSING
}

\author{
Nurmania Fitri ${ }^{1}$ Abdul Hadi ${ }^{2}$ Promadi $^{3}$ \\ English Study program of Postgraduate Program State Islamic University of Sultan \\ SyarifKasim Riau \\ Nurmania.fitri03@gmail.com
}

Received: 30 Oktober 2019; Accepted 12 Agustus 2021; Published 1 September 2021

Ed 2021; 2 (2): 153-158

\begin{abstract}
ABSTRAK
Tujuan penelitian ini adalah untuk mengetahui pengaruh kebiasaan membaca dan strategi membaca terhadap pemahaman membaca siswa di SMP Negeri 1 Kecamatan Benai-Kuansing. Ada tiga pertanyaan yang terkandung dalam penelitian ini. Pertama, Apakah ada pengaruh yang signifikan kebiasaan membaca terhadap pemahaman membaca siswa di SMP 1 Benai. Kedua, Apakah ada pengaruh yang signifikan dari strategi membaca terhadap pemahaman membaca siswa di SMP 1 Benai. Ketiga, Apakah ada pengaruh yang signifikan dari kebiasaan membaca dan strategi membaca terhadap kemampuan membaca siswa? pemahaman siswa di SMP Negeri 1 Benai. Penelitian ini menggunakan penelitian kuantitatif explanatory research. Subjek dalam penelitian ini adalah 70 siswa kelas II. Teknik pengumpulan data dalam penelitian ini menggunakan angket dan tes. Kuesioner dalam penelitian ini berkaitan dengan kebiasaan membaca siswa dan strategi membaca siswa, sedangkan tes berkaitan dengan pemahaman membaca siswa. Data yang diperoleh dianalisis dengan menggunakan statistik deskriptif, uji asumsi klasik, uji regresi berganda dan uji hipotesis. Hasil penelitian ini menunjukkan bahwa, kebiasaan membaca siswa (X1) memiliki hasil signifikan sebesar 0,685. Strategi membaca siswa (X2) memiliki hasil signifikan sebesar 0,379. Dan pemahaman bacaan siswa (Y) memiliki hasil signifikansi sebesar 0,818 . Oleh karena itu, peneliti menyimpulkan bahwa ada kontribusi positif dan signifikan dari kebiasaan membaca siswa dan strategi membaca siswa terhadap pemahaman bacaan siswa.
\end{abstract}

Kata kunci: Kebiasaan Membaca, Strategi Membaca, Pemahaman Membaca.

\section{THE INFLUENCE OF READING HABITSAND READING STRATEGIES ON STUDENTS' READING COMPREHENSION ATJUNIOR HIGH SCHOOL 1 IN THE DISTRICT OFBENAI- KUANSING}

\begin{abstract}
The purpose of this study was to the influence reading habits and reading strategies on students reading comprehension at junior high school 1 in the district Benai-Kuansing.There were three questions contained in this study.Firstly,Is there any significant influence of reading habit on students' reading comprehension in junior high school 1 Benai.Secondly, Is there any significant influence of reading strategies on students' reading comprehension in junior high school 1
\end{abstract}


Benai.Thirdly, Is there any significant influence of reading habit and reading strategies on students' reading comprehension in junior high school 1 Benai.This study used quantitative explanatory research. The subjects in this study are 70 students of the second grade students. Data collection techniques in this study used questionnaires and tests. The questionnaires in this study related to students' reading habits and students' reading strategies, while the tests related to student reading comprehension. The data obtained were analyzed using descriptive statistics, classic assumption tests, multiple regression tests and hypothesis testing.The results of this study indicate that, student reading habits (X1) have significant results of 0,685. Student reading strategies (X2) have significant results of 0.379. And student reading comprehension $(Y)$ has a significance result of 0.818 . Therefore, the researcher concludes that there is a positive and significant contribution of student reading habits and student reading strategies on student reading comprehension.

Keywords:Reading Habit, Reading Strategies, Reading Comprehension.

\section{INTRODUCTION}

Graves (2013) state that, language learners should be given insight into the place and function of various language items and skills in listening, speaking, reading and writing activities; that is, in real communication situation. Among these skills, reading is the fundamental skill. It is supported by Moats as cited in Westwood (2001) who states that reading is the fundamental skill upon which all formal education depends. In teaching reading at school, reading takes the position as one of language skill that should be taught. Harris (1991:1) states that reading ability is recognized as centrally important, since without it very little academic learning can be done.

In other hand people read for different purposes. According William in McDonough and Shaw (1993), some read for general information, some read for specific information, some other read for pleasure or interest. For that reason, comprehension becomes the most important factor to indicate how well the students read. In teaching reading comprehension, the teacher has to have a goal to minimize reading difficulties and to maximize comprehension by providing culturally relevant information. What the students read must be relevant to their need and interest and they must be ready, willing and able to read it (Pardo,2004:58).

However, as cited from The Jakarta Post ( August $29^{\text {th }}, 2016$ ), Indonesia ranks both out of 61 countries in term of reading interest, a study by central Connecticut state university in the US had revealed. The problem of reading has been found in young students. As reported in The Jakarta Post (July $4^{\text {th }}, 2014$ ), based on recent nationwide survey conducted by the United States Agency for International Development (USAID) in cooperation with the Education Ministry, Religious Affairs Ministry and Myriad Research, the reading ability of primary school students in Indonesia was 69 percent. It was found that many students were not able to read. If the primary students have a reading problem in the first language, undoubtedly junior high school students also have difficulties in reading, especially for English text. In addition, cited from The Jakarta Post (December $\left.21^{\text {st }}, 2002\right)$, many students, even at university level, are still weak in their reading comprehension.

According to the report of the commission on reading in the United States (Anderson, Heibert, Scott and Wilkinson, 1985) reading is cornerstone for success, not just in school but throughout life. Therefore, according to Nuttal (1982:37) it is very important to keep reading habit for the whole life. Reading habit is alleged to slow down the reader when they persist into later stages of reading. From the statement we know that reading 
habit is needed if we want to know more what we want to know. The commission noted "without the ability to read well, opportunities for personal fulfillment and job success will inevitably lose". In their research, Kirsch and Guthrie (1984) found that reading is necessary aspect for job and career development, especially in responding to change. They further reported that to the adults in their study. "reading is an inconsequential aspect of life outside the classroom"(Guthrie,2004).

Reading comprehension can be influenced by reading habit, especially by frequency of reading of the students. One way that we could apply in reading habit was by giving them more time in reading. Frequency of reading can be identified as a factor which can increase their reading comprehension. On the contrary, one who always read minimal 2 hours every day (reading with understanding), of course their knowledge was more than poor reading. Therefore, they would be easier to get the meaning from the text they read.

According to curriculum 2006, the students' score in reading comprehension should reach the KKM is 75, but in fact the students only could reach 60-70. This case at junior high school 1 benai, thus, encourage the writer to do further research to find the influence of reading and reading strategies toward reading comprehension. The writer chose it because good reading habit and reading strategies might contribute to student's reading comprehension. There are some factors that contributed for having good reading comprehension. Reading habit in learning process might determine the student reading comprehension because we could get the meaning of the text more effectively. If we read more books, it would increase our skill in comprehending the text we read. Good readers who read more books would have better comprehension of the text than poor readers

Based on pre-observation at SMPN 1 Benai, it was found out that the problems of students in learning foreign language, especially in English was their understanding of reading texts in English. It was because their lack of experience in learning English and their low motivation to learn it. The teachers usually only taught the foreign language by memorizing the meaning of words from the dictionary used by the students. The lack of understanding in learning a foreign language caused the students not to be motivated to learn English even further. They did not know what they should do to comprehend reading texts in English. But if the learners are trying to know how to learn, how to use specific strategies, and how to make good study habits as a routine practice, they will improve the likelihood of success. As Rubin (1975: 41) stated that the different success of second or foreign language suggests a need to examine in detail what strategies successful language learners employ. An indication is given of what these strategies might consist of and list of several widely recognized good learner strategies are given. Teachers can improve their performance by paying more attention to learner strategies already seen as productive.

Another factors influencing students reading comprehension is reading strategies. Reading strategies are very important to help reader comprehend the text in the act of reading (Kuru- Gonen, 2015, p. 2924) and the implementation of special reading strategies enable more efficient use of time (Sen, 2009, p. 2301). Moreover, it is effective way to solve reading problems encountered by students while reading academic material (Lien, 2011, p. 200). Reading strategies are defined as the comprehension processes that readers use in order to make sense of what they read that categorized as approaches, actions, and procedures used to improve reading comprehension (Brantmeier, 2002, p. 1). Research studies on second/foreign language reading have consistently confirmed the importance of reading strategies on developing language learners' reading comprehension skills (Zare and Nooreen, 2011; Brantmeier, 2002; Slataci and Akyel, 2002; C). They argue that strategy use is different in more and less proficient readers, who use the strategies in 
different ways. Moreover, it has been acknowledged that readingstrategies can be taught to learners and that reading strategy instruction can benefit all students (Carrell, 1989; Carol, 2002).

The role of strategy use in reading comprehension has been a topic of discussions in secondforeign reading literature. Reading strategies are very essentialto assist learners to overcome reading difficulties such as inferring the underlying messages in the texts, dealing with unknown terms and unfamiliar cultural load (Lien, 2011, p. 200; KuruGonen, 2015, p. 2924). It implies that being a strategic reader help reader comprehend the text and handle the reading problems. Effective strategies will produce an effective result. Skilled readers know how to use affective strategies to facilitate the functioning of various cognitive process and construct meaningful understanding of the text, poor readers simply read the text word by word without using any strategies (Lau and Chan, 2003, p. 13).

\section{METHODOLOGY}

This researchit was conducted through a quantitative approach. According to Creswell, A correlation is a statistical test to determine the tendency or pattern for two or more variables or two set of data to covary constantly. In this term of quantitative data, statical analysis was used to calculate the numeral data that were gathered and analyze them by the use of correlation analysis. Correlational research is a type of non-experimental research in which the researcher measures two variables and assesses the statistical relationship between them with little or no effort to control extraneous variables (Price, 2012:171).

This quantitative research,in this research, the researcher distributed the questionnaire to the students to know their reading habit and reading strategies score and to get information reading habits. Questionnaire is a data collection technique in which participants fill in questions or statement then after they are completely returned to the researcher (Creswell 2016:192). In determining students score, the researcher used closed questionnaire in which the respondents ticked the available responses provided in the questionnaire. Process learning and teaching activities need an evaluation measure ability students, one of the options is the multiple choice test (Anderson \&Krathwohl, 2001).A test is a systematic procedure for observing one's behavior and it with the aid of numerical or category system. Multiple choice test is a test used to measure students ability to think (Nitko\& Brookhart,2011).A test is used to collect the data of students' reading comprehension.

In this research, all data were gained from the result of the questionnaire and reading test score in the form of numbers. All data therefore were analyzed quantitatively. Since this research was to know the correlation between two variables, the researcher applied Bivariate Correlation Analysis by using Pearson Product Moment technique and Multiple Regression. The researcher used it because the data obtained from two variables were exposed in terms of quantitative scores and the data was using interval scale (Arikunto, 2006). Pearson Product Moment coefficient of correlation was used when the scale of measurement was either interval or ratio. Therefore, the Pearson $r$ was the appropriate correlation coefficient to calculate. 


\section{FINDINGS}

Based on analyzing data with person product moment we can see that table below, the researcher found significant influence of students reading habit and reading strategies on reading comprehension. It is explained on the table below:

\begin{tabular}{|c|c|c|c|c|}
\hline \multicolumn{5}{|c|}{ Correlations } \\
\hline & & $\mathrm{X} 1$ & $\mathrm{X} 2$ & $Y$ \\
\hline \multirow{3}{*}{$\mathrm{X} 1$} & $\begin{array}{l}\text { Pearson } \\
\text { Correlation }\end{array}$ & 1 & $.818^{* *}$ & $.685^{* *}$ \\
\hline & Sig. (2-tailed) & & .000 & .000 \\
\hline & $\mathrm{N}$ & 70 & 70 & 70 \\
\hline \multirow{3}{*}{$\mathrm{X} 2$} & $\begin{array}{l}\text { Pearson } \\
\text { Correlation }\end{array}$ & $.818^{* *}$ & 1 & $.739^{* *}$ \\
\hline & Sig. (2-tailed) & .000 & & .000 \\
\hline & $\mathrm{N}$ & 70 & 70 & 70 \\
\hline \multirow{3}{*}{ Y } & $\begin{array}{l}\text { Pearson } \\
\text { Correlation }\end{array}$ & $.685^{* *}$ & $.739^{* *}$ & 1 \\
\hline & Sig. (2-tailed) & .000 & .000 & \\
\hline & $\mathrm{N}$ & 70 & 70 & 70 \\
\hline & elation is sig & the 0. & vel (2 & ed). \\
\hline
\end{tabular}

Based on the table, it can be seen that correlation between reading habits and reading strategies on reading comprehension is 0.685 . Two star sign $(* *)$ means correlation because the direction of the correlation coefficient number is positive, the correlation between the two variables on the other words the increasing reading habit and reading strategies will increase reading comprehension. Based on hypothesis there is significant influence reading habits and reading strategies on reading comprehension this accepted while that state no significant influence of students reading strategies on reading comprehension is rejected.

\section{CONCLUSION}

The findings indicate that there is significant difference between reading habits and reading strategies on students' reading comprehension. For both of them show the significant effect on the students' reading comprehension. In this research, the conclusions are made based on the previous discussion. Those are as follows: There is a positive and significant of the reading habit and reading strategies on students' reading comprehension. Reading habit on reading comprehension with Rxy $(0,685)$ is in the interval $0.40-0.70$. It means that the relationship between students' reading habit and their reading comprehension was on moderate correlation. Then, reading strategies on reading comprehension with Rxy (0.739)is in the interval $0.71-0.90$. It means that the relationship between students' reading strategies and their reading comprehension was on high correlation. It means that reading comprehension is increasing bykeeping on gaining a good reading habit and reading 
strategies of the students. There is a positive and significant contribution ofreading habit and reading strategies on students reading comprehension. In order to improve students' readingcomprehension, teachers should teach the students about strategies in reading andmotivate them with giving an interesting activity. However, the reading habits contributes a little bit more effect compared to readingstrategies. As a reading strategies, it is found that good readers are aware of what they are reading and why they are reading it, in addition, they use some plans and strategies to monitor their own understanding and overcome the problems they face while reading. Reading as a habitual activity also helps the student to increase their understanding, helps them become more intelligent, and boosts their vocabulary meaning. Reading comprehension build the readers are able to comprehend the meaning of the text. If the readers can read but do not comprehend the meaning of the text, it means they do not do reading comprehension.

\section{REFERENCES}

Anderson, M. and K. Anderson. 1997. Text Types in English 1. Australia:Macmillan Education.

Arikunto, S. 2006. Prosedur Penelitian Suatu Pendekatan Praktik. Jakarta:Rineka Cipta.

Brantmeier.C. (2002). Second language reading strategy research at the secondary and university levels: Variations, disparities, and generalizability. The Reading Matrix, 2(3), 1-14. Retrieved from http://www.readingmatrix.com/articles/brantmeier/article.pdf.

Cohen et. al. 2007. Research Method in Education. New York: Routledge.

Creswell, J.W. (2009). Research Design Third Edition. California: SAGE Publications, Inc.

Creswell, John W. (2012). Educational Research : Planning, Conducting and Evaluating Quantitative and Qualitative Research, Fourth Edition. Boston: Pearson Education, Inc. WW

Graves, M.F et. al. 2013.Teaching Vocabulary to English Language Learners.

New York: Teachers College Press.

Harris, Albert J. 1990. How to Increase Reading Ability: A Guide to Developmental \& Remedial Methods, fifth edition, New York: David McKay Company, Inc.

Krashen, S. 2004. The Power of Reading: Insight from the Research. Portsmouth: Heineman

McDonough, J.,\& Shaw, C.1993. Material and Methods in ELT.Oxford UK: Blackwell.

Nuttal, Christine. 1982. Teaching Reading Skill in a Foreign Language. London: Heinemann Educational Books.

Nunan, D. (2003). Practical English language teaching.New York: McGraw Hill Company. 